\title{
Occurrence of Cytospora castanae sp. nov., associated with perennial cankers of Castanea sativa
}

\section{Dar MA and Rai MK*}

Department of Biotechnology, Sant Gadge Baba Amravati University Amravati-444602., Maharashtra, India. "mkrai123@rediffmail.com

Dar MA, Rai MK 2014 - Cytospora castanae sp. nov., associated with perennial cankers of Castanea sativa. Mycosphere 5(6), 747-757, Doi 10.5943/mycosphere/5/6/5

\begin{abstract}
The Chestnut (Castanea sativa Mill.) population in India is confined to the northern part of the country, which is continuously destroyed by natural (diseases/pests) and anthropogenic disturbances. Chestnut diseases like cankers and blight are mainly caused by fungi. Attempts were made to isolate the important fungal pathogen of chestnut trees. We isolated fungal isolates from samples of infected chestnut trees, which are confirmed as a new species of the genus Cytospora, family Valsaceae, with unique morphological and molecular characters. The initial identification of the fungus was based on morphological characters, and later confirmed by molecular studies. The phylogeny of the fungus was determined by rDNA-based phylogenetic markers ITS (Internal Transcribed Spacers) with the help of phylogenetic tools and were used for molecular identification and differentiation of the fungus. Phylogenetic analysis of the unknown fungus showed isolates reside in a clade separate from other species of genus Cytospora. Cytospora castanae sp. nov., therefore, is a new species of the genus Cytospora, witnessed by its morphological and molecular characters.
\end{abstract}

Keywords - Cryphonectria - India - ITS - rDNA - Phylogeny

\section{Introduction}

Cytospora species are among the most common and prevalent canker and dieback-causing fungi on trees, shrubs and herbaceous plants resulting in considerable economic losses worldwide (Fotouhifar et al. 2010). Over 85 species of woody tree and shrub hosts are susceptible to Cytospora canker, which are also termed as perennial canker or Valsa or Leucostoma canker (Wang et al. 2011); usually, infecting the inner bark or bark periderm. Cytospora diseases affect the cultivation of fruit trees and limit the productivity and longevity of shrubs and trees (Adams et al. 2006). Cytospora cankers are especially destructive on Prunus, Picea, Acer, Populus etc. (Farr et al. 1989). Cytospora sp. is highly virulent on cultivated Prunus (Biggs 1989) and Populus species (Kepley \& Jacobi 2000). Many of these fungi are considered facultative wound parasites that attack weakened trees. The pathogencity can be considered species specific but this character of pathogencity is difficult to determine (Adams et al. 2006).

Cytospora is considered as asexual stage of the genus Valsa (Sexual stage) (von Hoehnel 1917, Adams et al. 2006) which also acts as canker causing pathogen in apple, Chinese scholar tree, peach, plum, popular, and many more tree species (Adams et al. 2006, Kirk et al. 2008, 
Fotouhifar et al. 2010, Mehrabi et al. 2011, Wang et al. 2011, Fan et al. 2014). von Hoehnel (1917), described the clarification of Valsa and Cytospora species as sexual and asexual stages, respectively. This clarification was followed by many taxonomists (Grove 1923, Gutner 1935, Defago 1942, Urbanz 1957, Hubbes 1960) to describe the sexual (Teleomorph) and asexual (Anamorph) stage of the genus Valsa (Adams et al. 2006). Cytospora species are the anamorphs having fruiting bodies consisted of stromata (conidiomata) that usually contain either intricate chambers or clusters of pycnidia, with filamentous branched conidiophores and hyaline allantoid conidia, exuding from the fruiting bodies as yellow, orange or red tendrils or gelatinous drops (Adams et al. 2006).

In India, Cytospora spp. are reported from a number of hosts; Cedrela toona, Mangifera indica, Salix alba, Pyrus malus, Prunus persica, Acacia arabica, Syzyzium cumini, Pongamia pinnata, Euclyptus sp. etc. (Sydow \& Buttler 1916, Grove 1923, Singh 1943, Tilak \& Rokde 1964, Sharma \& Agarwal 1974, Soni et al. 1983, Rajak et al. 1988). Most of these tree hosts are from the Central India, bearing tropical climatic conditions. In temperate region i.e North part of the country only one species of Cytospora salicis (Corda) Rabenh, has been reported from Salix alba (Grove 1923).

In the present study, the chestnut cankers in Jammu and Kashmir, India were studied for the isolation of Cryphonectria species. We obtained a new species of Cytospora responsible for stem cankers in this tree species.

\section{Materials and Methods}

\section{Fungal Cultures and Morphology}

Collection of the samples of infected chestnut trees were made from the District Baramulla, Jammu and Kashmir State, India. Samples were collected from different infected (cankered) chestnut trees. Samples of $4-5 \mathrm{~cm}$ were taken from bark pieces of the infected dead chestnut stems. From these bark pieces, $5-6 \mathrm{~mm}$ small pieces were cut by cork-borer and were surface sterilized with $90 \%$ alcohol for 60 seconds. These surface sterilized bark pieces were placed on to Potato Dextrose Agar (PDA) in Petri-plates. The inoculated plates of PDA were incubated for 7-9 days at room temperature $25^{0 \pm} 2^{0} \mathrm{C}$. The colonies of the fungus were obtained within 8 days after inoculation. The pure cultures of the isolates were obtained using single spore isolation method described by Choi et al. (1999). The isolates were incubated on 2\% potato dextrose agar (PDA) medium. On PDA, the fungus showed dark- brown or black pigmentation. The cultures have been deposited in culture collection centre of the SGB Amravati University with accession numbers AUCCT/DBT 183, 188, 293, 354 and MycoBank submission number (MB 808545).

Dark colored fruiting bodies of the isolates were present on the bark of the chestnut trees. Structures were examined with illuminated light microscope (Carl Zees with digital camera). Measurements are reported as the maximum, average and minimum values of observations. Fruiting structures were cut from the bark specimens and examined under the microscope by macerating in $3 \% \mathrm{KOH}$ in order to study conidiophores conidiogenous cells and conidia. Conidia and conidiophores were measured and are presented values in $\mu \mathrm{m}$.

\section{DNA Extraction and PCR Amplification of ITS Region}

Cultures of the fungus were used for the isolation of DNA for the purpose of molecular identification by using molecular marker such as rDNA based ITS (Internal Transcribed Spacers) markers. The DNA isolation was carried out using kit method provided by Chromous Biotech Pvt. Ltd., Bangalore. DNA samples of the fungus were amplified for the ITS regions using primers ITS1 and ITS-4 with a total volume of $25 \mu \mathrm{L}$ (Fotouhifar et al. 2010). Reaction components included $2.5 \mu \mathrm{L}$ of $10 \times$ PCR buffer (Takara Bio, Inc.), $2.5 \mu \mathrm{L}$ dNTPs, $1.25 \mu \mathrm{L}$ of $10 \mu \mathrm{M}$ forward and reverse primers, $0.75 \mathrm{U}$ ExTaq (Takara Bio, Inc.), and $1 \mu \mathrm{L}$ DNA template. Cycling conditions included an initial denaturation at $95^{\circ} \mathrm{C}$ for $2 \mathrm{~min}$ followed by 35 cycles with a denaturation step at $94.5^{\circ} \mathrm{C}$ for $1 \mathrm{~min}$, annealing at $56^{\circ} \mathrm{C}$ for $1 \mathrm{~min}$, extension at $72^{\circ} \mathrm{C}$ for $1 \mathrm{~min}$, followed by a final 
extension at $72^{\circ} \mathrm{C}$ for $5 \mathrm{~min}$. PCR products were purified with QIAquick spin columns (QIAGEN). All DNA fragments for ITS region were sequenced Samved Biotech Pvt. Ltd. using the Applied Biosystems Automated 3730 DNA Analyzer with Big Dye Terminator chemistry and Ampli-TaqFS DNA Polymerase. All gene regions were sequenced in both directions in at least one isolate.

\section{Sequencing and Phylogenetic Analysis}

Sequences were obtained from rDNA based ITS regions of fungal isolates from Chestnut, Jammu \& Kashmir, India. These sequences were compared with those already published in NCBI. All ITS regions were sequenced in both directions in at least one isolate. Sequences of ITS regions were deposited in NCBI GenBank with accession numbers KC963921, KC963923, KC963924 and KC963957. All sequences were compared with other species using NCBI, BLAST.

DNA sequences from this study and those retrieved from GenBank were aligned with ClustalW2 (EMBL-EBI) (Larkin et al. 2007). The alignments were checked visually and improved manually where necessary. All sites were used for analysis. Sequences of Cryphonectria sp. and Gnomoniopsis smithogilvyi isolated from infected chestnut trees (same host) of India, were used as outgroup. Phylogenetic analyses were performed with MEGA6 (Tamura et al. 2013). Trees were produced using Maximum Likelihood (ML) analysis for the ITS sequence dataset. For ML analysis, the heuristic search option Nearest-Neighbor-Interchange (NNI) was used with very strong branch swap. Stability of clades was assessed with 1000 bootstrap replications in a heuristic search. Other measures used were tree length, consistency index (CI), retention index (RI), rescaled consistency index (RC) and homoplasy index (HI). Tree matrices and phylogenetic tree (Fig. 1) were submitted in TreeBASE with submission ID: 14689.

\section{Results}

\section{Molecular identification (DNA amplification and sequencing) and phylogeny}

The phylogenetic analysis was carried out using ITS sequence region. Corresponding phylogenetic tree was generated with sequences from the different isolates obtained in this study together with those of other Cytospora species from database. BLAST comparison of the sequences gave a similarity (>90\%) within each set. For each locus, the closest sequences were those from the genus Cytospora formed a close clade (Fig.1).

The evolutionary history was inferred by using the Maximum Likelihood method based on the Tamura-Nei model (Tamura \& Nei 1993). The tree with the highest log likelihood (-7939.4524) is shown (Fig.1). The percentage of trees in which the associated taxa clustered together is shown next to the branches. Initial tree (s) for the heuristic search were obtained automatically by applying Neighbor-Join and BioNJ algorithms to a matrix of pairwise distances estimated using the Maximum Composite Likelihood (MCL) approach, and then selecting the topology with superior log likelihood value. A discrete Gamma distribution was used to model evolutionary rate differences among sites $(5$ categories $(+G$, parameter $=1.1286)$ ). The rate variation model allowed for some sites to be evolutionarily invariable $([+I], 11.5456 \%$ sites). The tree is drawn to scale, with branch lengths measured in the number of substitutions per site. The analysis involved 75 nucleotide sequences. All positions containing gaps and missing data were eliminated. There were a total of 1805 positions in the final dataset. Evolutionary analyses were conducted in MEGA6 (Tamura et al. 2013).

Isolate sequences representing species from NCBI database and the sample sequences formed separate clads. The fungal isolates from Indian chestnut (represented by square bullets) grouped separately formed a clade closer to Cytospora. Unlikeliness was most pronounced between the isolate sequences from India and those obtained from NCBI gene bank. The Indian isolates formed nearest sub-clad with Cytospora ambiens, which was also reported from the same host (Lindner 2013). This phylogenetic distinction between two species can be clearly seen in morphology. suggesting these isolates from India represent a new species in genus Cytospora. 


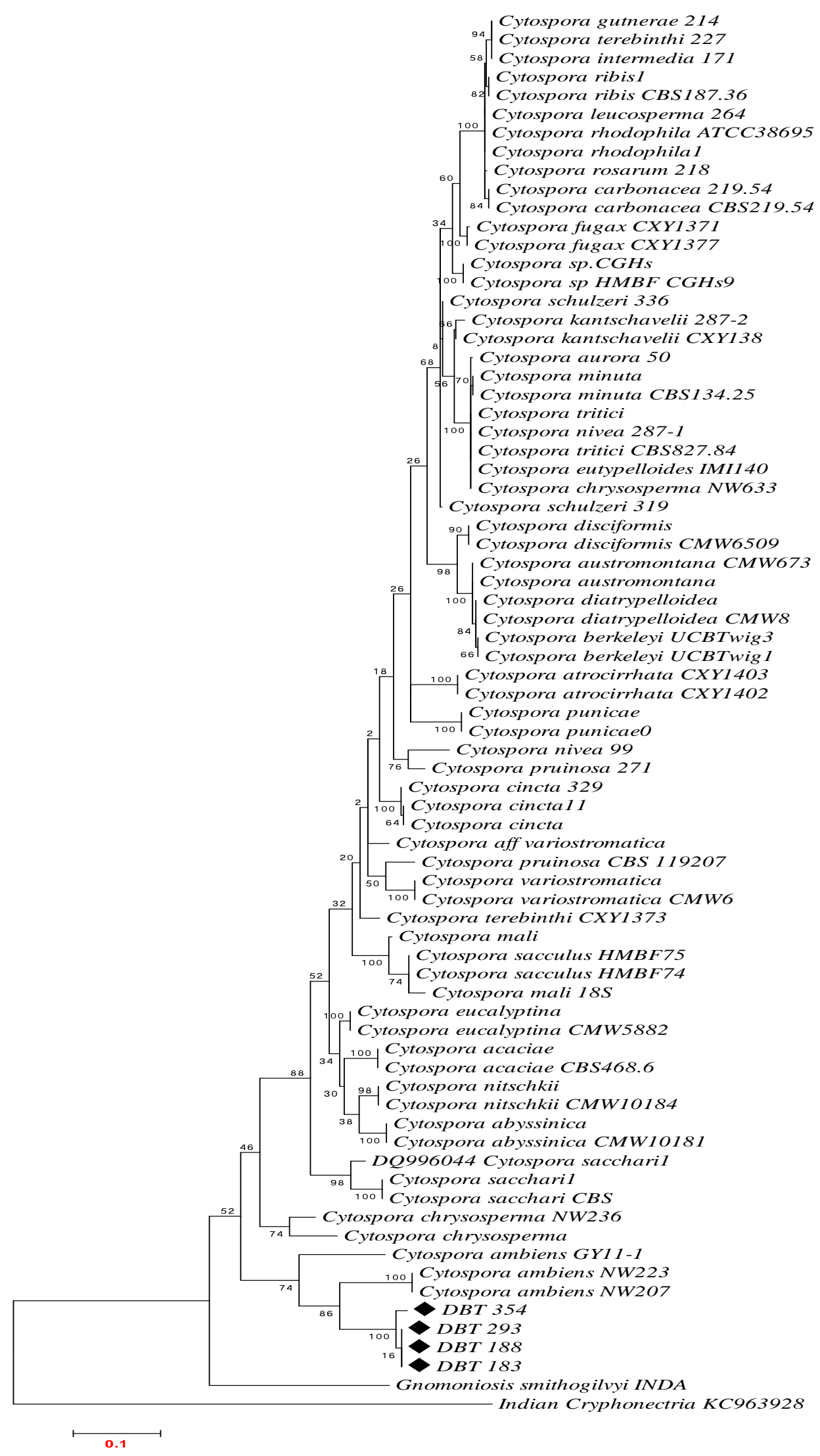

Fig. 1 - A phylogram obtained from the ribosomal DNA gene sequences. The evolutionary history was inferred using the Maximum Likelihood method. The Maximum Likelihood tree was obtained using the Tamura and Nei Model. Bootstrap values (1000 replicates) of branches are indicated on the branches and isolates representing the new species is represented by prefixed dark bold bullets. Groups include species of Cytospora, Cryphonectria and Gnomoniopsis. 


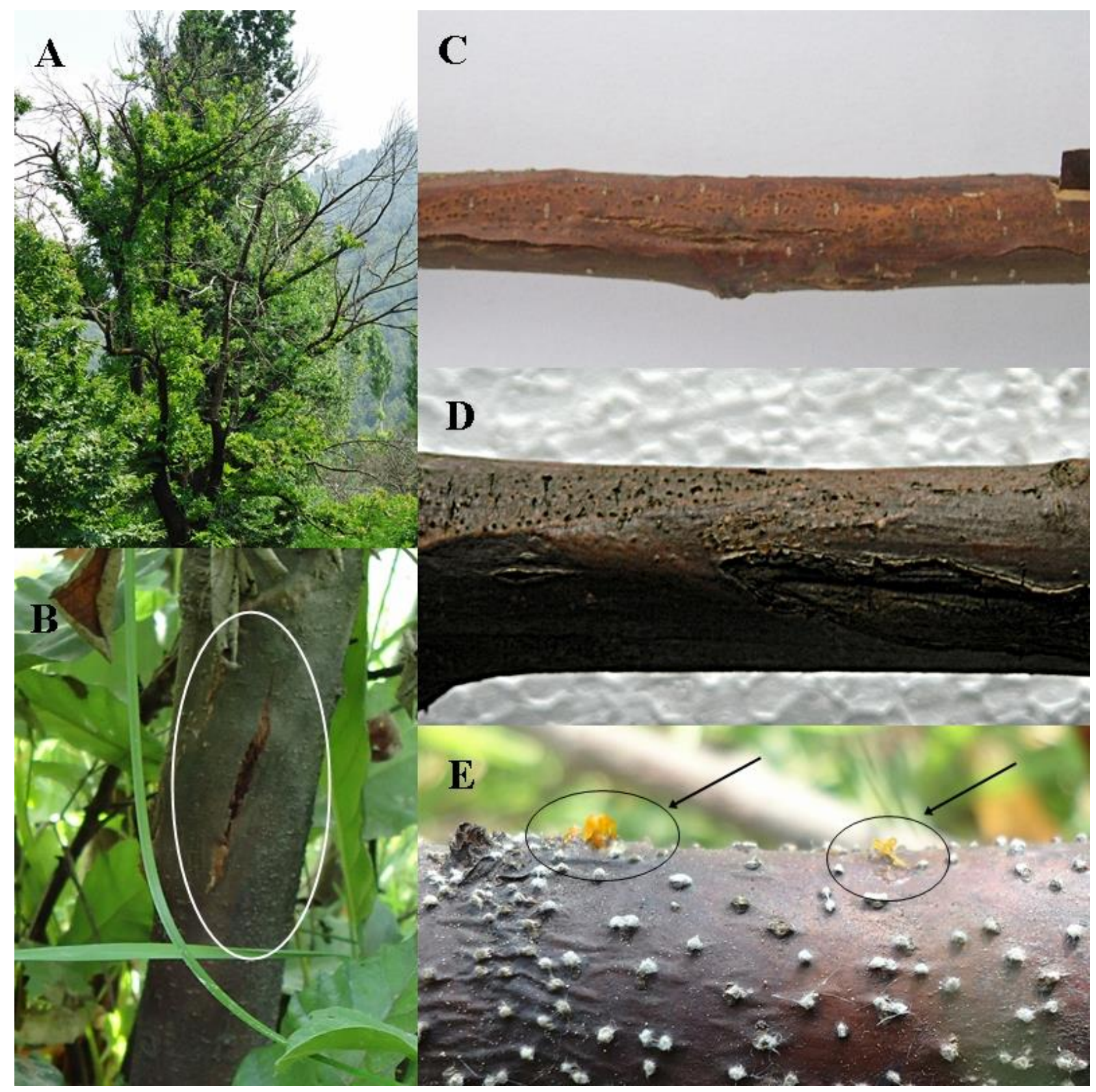

Fig. 2 A-E -Photograph showing chestnut tree A Blighted dead tree B Cankered young stem C Stem showing fruiting bodies with orange coloration D Stem showing black structures fruiting structures E Conidia oozing out of the fruiting body as a yellow to orange colour tendril.

\section{Taxonomy}

Cytospora castanae Dar \& Rai, sp. nov. Mycobank MB 808545

The morphology of the fungus isolated from Chestnut (Castanea sativa Mill.) in India was similar to that of species of genus Cytospora. Disease starts as orange spots gradually changing black, developing pimple like dark structures. The lesions are irregular on the bark (Fig.2) and the stromata appear as black pinhead spots on the lesions, conidia come out of the stroma as yellow color tendrils. Pycnidia are stromatic, stroma erumpent, rosette, labyrinthine, initially orange in color darkens with maturity changing to black color, completely embedded and depressed in the host tissue and discs are black, nearly circular and flat. Each stroma bears 6-10 pycnidia, joined to a single ostiole black in color with profuse cottony growth at opening, $1-2.5 \mathrm{~mm}$ in diam and furfuraceous, with a white cottony growth at the tip, with single opening. Pycnidial locules are multi-chambered, subdivided by invaginations, sharing common pycnidial walls, $200 \times 150 \mu \mathrm{m}$ in size (Fig.3). Pycnidial walls white in color, separates from stromata at maturity (Fig.3). 


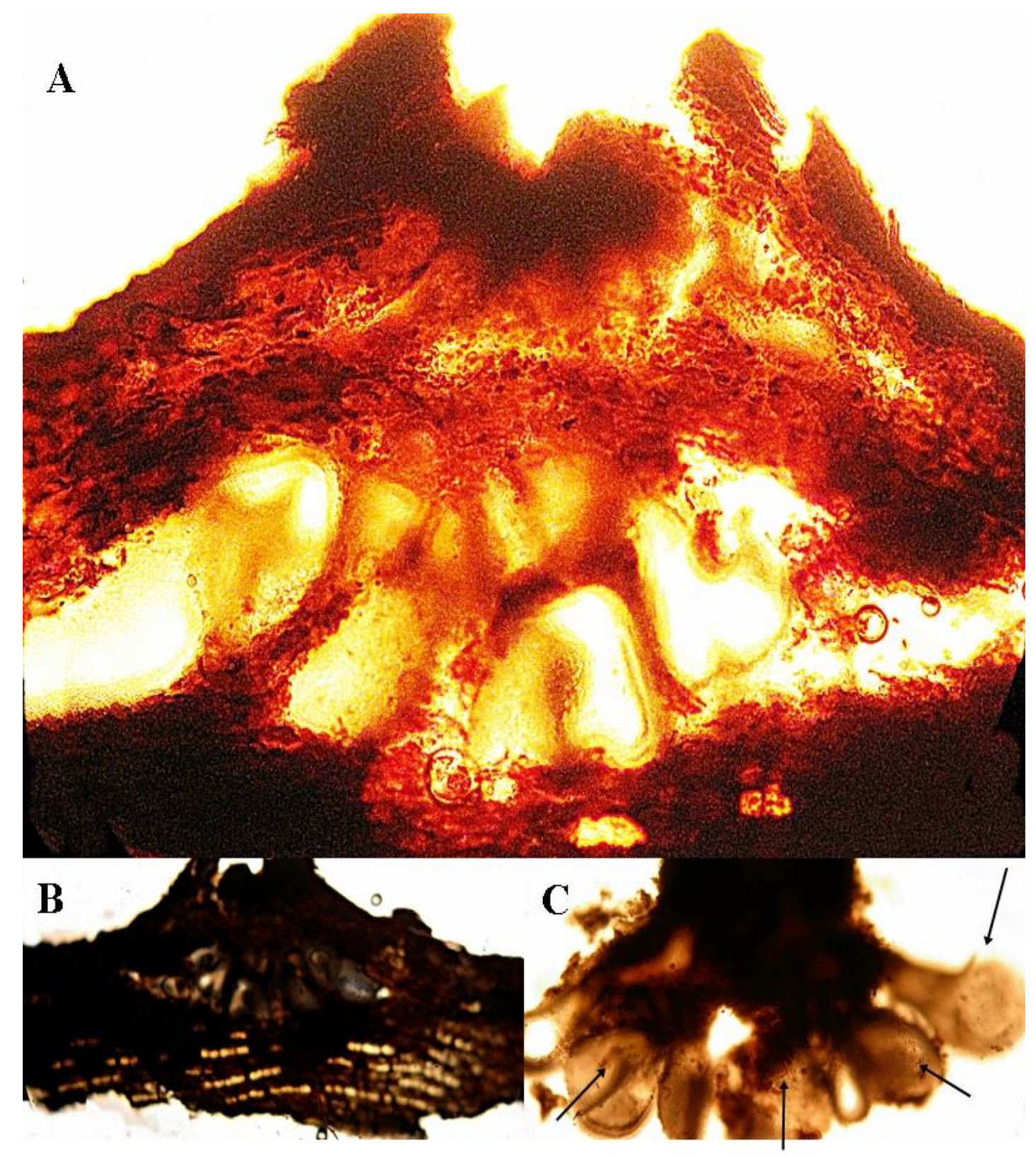

Fig. 3 A-C - Micrographs showing fruiting structure of Cytospora sp. A Stromatic pycnidia orange in color B Pycnidia at late stage C Pycnidia attached to a common ostiole

Conidiophores are hyaline, branched both at base and above the base, cyclindrical, 14$27 \times 1.5 \mu \mathrm{m}$ in size with an average size of $19 \times 1.5 \mu \mathrm{m}$, bearing a single conidia at each tip (Fig.4). Conidiogenous cells are cylindrical, tapers at apices, with a range of size between $7-10 \times 1 \mu \mathrm{m}$; $9 \times 1 \mu \mathrm{m}$ average size. Conidia hyaline, slightly curved, aguttulate, elongated, singlecelled, aseptate, and size $3.5-6 \times 1 \mu \mathrm{m}$; average $5 \times 1 \mu \mathrm{m}$. The conidia ooze out of the pycnidia through ostiole in form of a yellow color tendril (Fig.2E). On PDA isolates showed black color on the dorsal and ventral side of plates (Fig.5), the mycelium was dark little cottony growth and with slightly smooth margins. The growth of fungus was fast, taking about 7- 9 days for growth on petriplate of $80 \mathrm{~mm}$ distance at $25^{\circ} \mathrm{C}$ (Fig.5).

Type material - INDIA, Jammu and Kashmir, Srinagar, on chestnut (Castanea sativa Mill.) bark, June 2011, AUCCT/DBT 183 (Holotype, Bp) Sequences of the type specimen have been submitted to GenBank under the accession numbers KC963921 (ITS1-5.8S-ITS2).

Etymology - Latin, 'associated with cankers on chestnut (Castanea sativa) trees' referring to the fact that this species has been reported first time from Castanea $\mathrm{sp}$. 


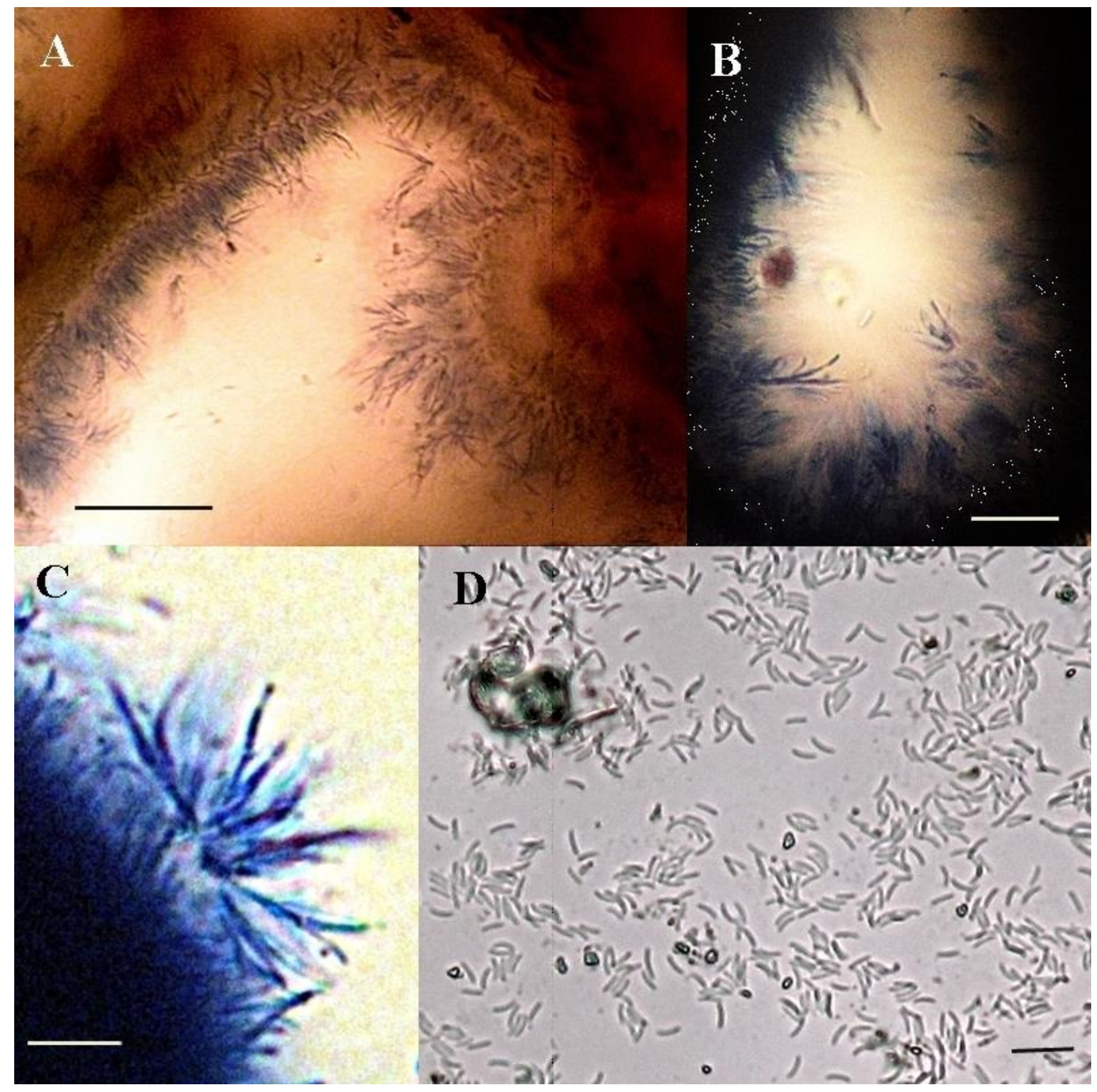

Fig. 4 A-D - Micrographs showing fruiting structure of Cytospora sp. A-B Pycnidia C Conidiophores D Conidia Bars: $\mathrm{A}=100 \mu ; \mathrm{B}=50 \mu ; \mathrm{CD}=10 \mu$

Description - Lesions formed irregular, initially orange changing to black; stromata appear as black pinhead spots on the lesions; pycnidia stromatic, stroma erumpent, rosette, labyrinthine, initially orange changing to black color, embedded and depressed; discs black, circular and flat. Stroma bears 6-10 pycnidia, joined through ostiole, ostiole black furfuraceous. Pycnidial locules multi-chambered, subdivided by invaginations, common pycnidial walls, $200 \times 150 \mu \mathrm{m}$; pycnidial walls white in color, separates from stromata at maturity; conidiophores hyaline, branched both at base and above the base, cylindrical, $14-27 \times 1.5 \mu \mathrm{m}$ (average $19 \times 1.5 \mu \mathrm{m}$ ); bearing a single conidium at each tip; conidiogenous cells cylindrical, tapering apices, size $7-10 \times 1 \mu \mathrm{m}$ (average $9 \times 1 \mu \mathrm{m}$ );

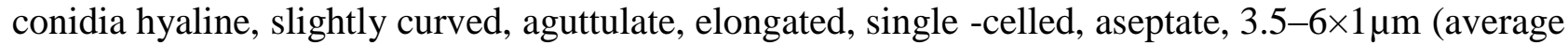
$5 \times 1 \mu \mathrm{m}$ ); conidia come out through ostiole in form of a yellow color tendril; On PDA isolates black color dorsal and ventral side; mycelium septate, dark, cottony, smooth margins.

Substrate and habitat - Growing on chestnut trees, causing cankers on chestnut bark.

Distribution - North India (especially Jammu and Kashmir State) 

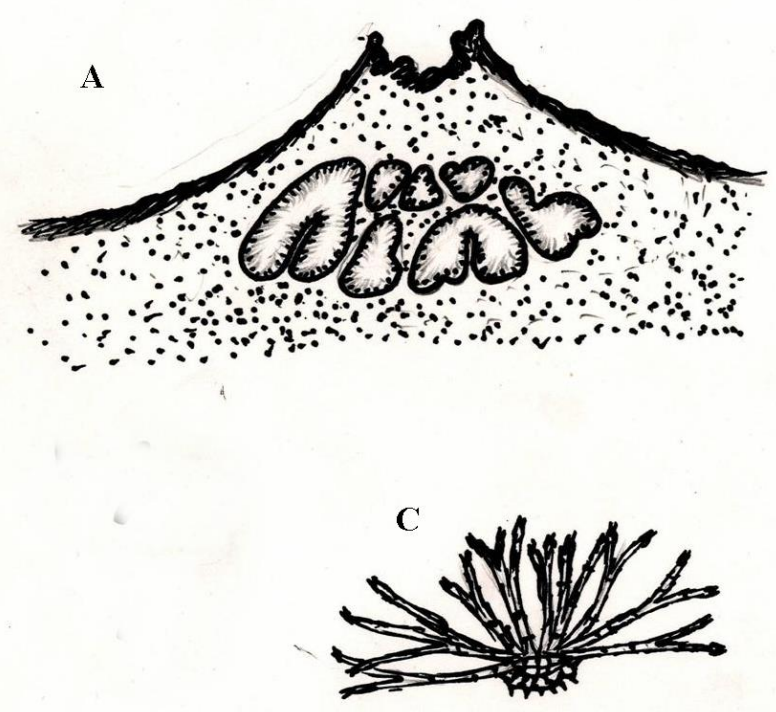

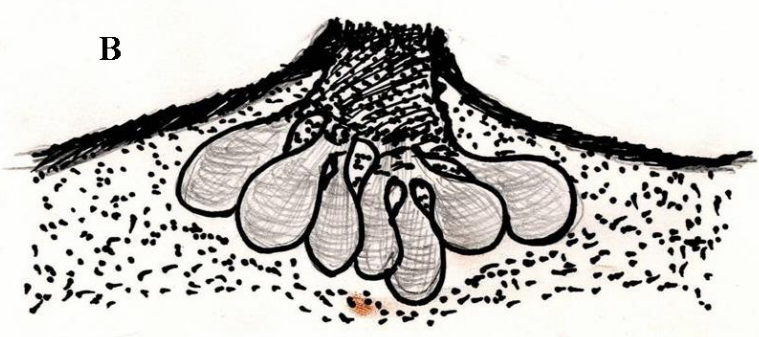

$$
\text { D popala }
$$

Fig. 5 A-D - Sketches (Fruiting structures of Cytospora sp.) A Stromata of Cytospora, bearing Pycnidia B Pycnidia united to common ostiole C Conidiophore D Conidia
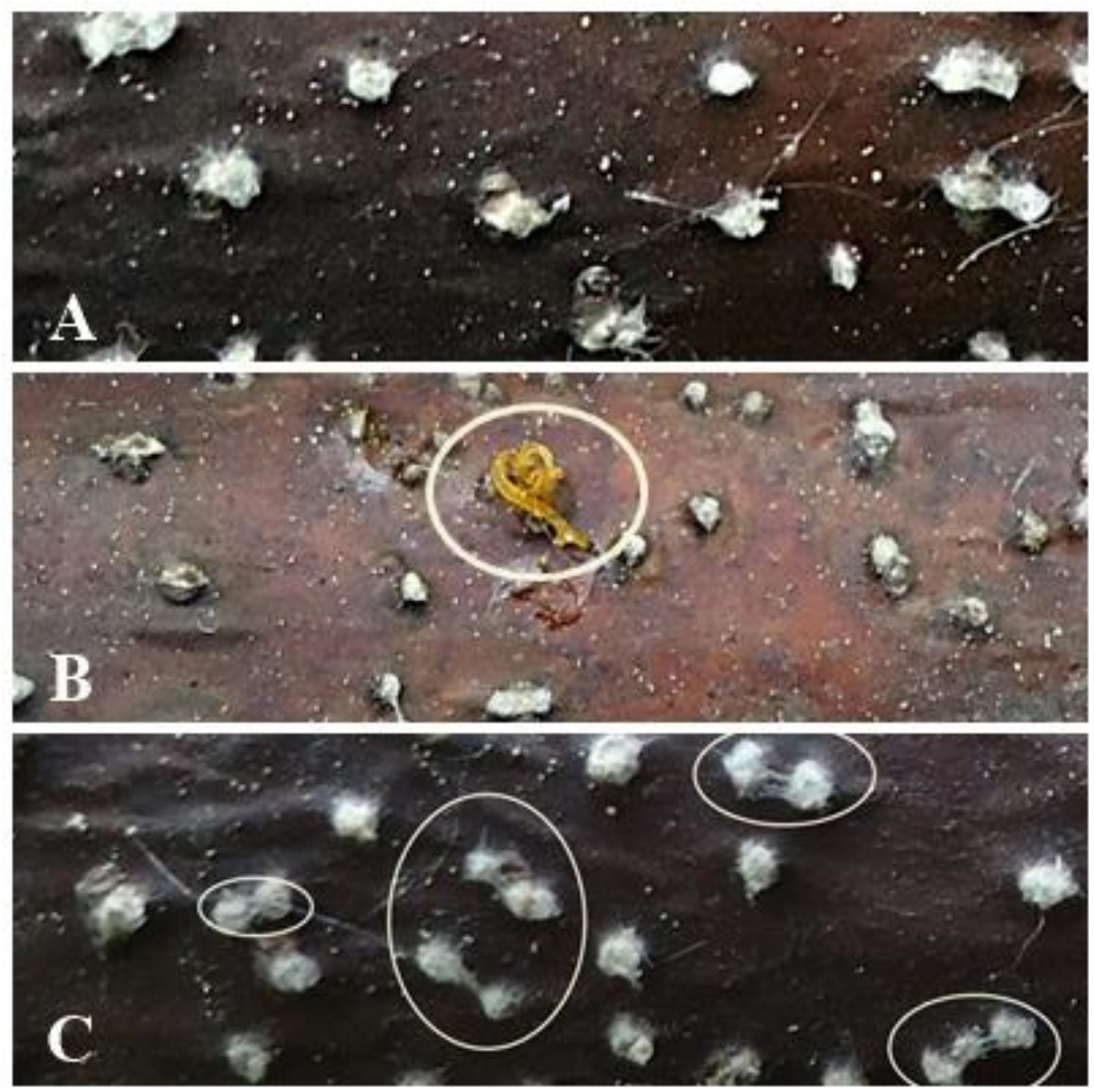

Fig 6 A-C - Photograph showing ostiole opening on lesions A Cottony growth B conidia tendril oozing out through ostiole $\mathrm{C}$ Cottony growth connections between neighbouring ostioles. 


\section{Discussion}

Species of Cytospora and associated teleomorphs cause annual or perennial cankers in trees and or rarely herbaceous plants. Infected plants get weakened and are stressed or injured and may show symptoms throughout the growing season (Agrios 2005). In the present study, many isolates of Cytospora were isolated from infected branches, twigs and stems of chestnut trees. The stem canker disease caused by the Cytospora sp. described in this study appears to be a serious disease of Castanea sativa in India. The outward symptoms of the disease are similar to those caused by Cytospora sp., but morphological and DNA based comparisons have shown clearly that the pathogen represents a distinct species. This is why we provided the name $C$. castanea for this fungus, which is clearly an important pathogen on Castanea sativa in North India.

Although similar to other Cyospora species in morphology, but $C$. castanea could clearly be distinguished from other species of genus. Based on DNA sequences differences, $C$. castanea grouped separately from known Cytospora sp. The most pronounced features supporting this phylogenetic distinction is change in stromata color during different stages of maturation, conidiomata detach from stromata at full maturity (Fig.3). In addition, conidia ooze out through ostiole as a yellow color small tendril (Fig.2). Also, the ostiole outside the bark bear profuse cottony growth, which make connections to neighboring ostioles (Fig.6C) and cover whole ostiole opening (Fig.6AC). These characters are prominent to differentiate the $C$. castanea from other known species of Cytospora.

DNA sequencing based molecular approaches has become necessary to taxonomy and for species allocation of many fungal groups. This principally applies to the taxa that have a limited number but extremely variable, morphological characters, such as genera and species of Valsaceae (Adams et al. 2005, 2006). In this study we collected many specimens of Cytospora genus from perennial cankers, occurring on chestnut plants. These specimens are new records for the mycobiota, and none has reported this species of Cytospora from anywhere before this investigation. Phylogenetic analyses based on nucleotide sequences of ITS region including ITS15.8S-ITS2 of ribosomal DNA grouped the Indian isolates of Cytospora, into a distinguishable clad. We considered this clad with the exception in the group, as phylogenetic lineages representing a distinct species. Overall clustering of Cytospora, Cryphonectria and Gnomoniopsis sequences into distinguishable clades is consistent with morphological characters. These groups show remarkable discrimination in their fruiting structures in nature too. In this study species correspond to single species formed a single clad. The sequence of isolates from Cryphonectria and Gnomoniopsis used in this analysis are either pathogens or saprophyte to same host chestnut tree, isolated from various places (Dar \& Rai 2013, 12).

The phylogenetic analysis also depicted an interesting approach by clustering the Indian Isolates closer to the $C$. ambiens Sacc. isolates, which predicts a relationship between the two species. This relationship may be due to the common host (chestnut) for infection (Adamčíková et al. 2013, Spaulding, 1961), but the morphology of the Indian isolates differentiates them from $C$. ambiens. Indian isolates have one-celled conidia elongated slightly curved and narrower than $C$. ambiens, which is characterized by one-celled conidia with elliptical and elongated shape (Adamčíková et al. 2013, Lindner 2013, Spielman 1985). Also the conidia in C. ambiens ooze out in a long orange colored tendril (Adamčíková et al. 2013, Lindner 2013) compared to Indian isolates the tendril is small yellow colored. The cottony growth at the ostiole opening of Indian isolates also makes it different from $C$. ambiens. In $C$. ambiens stromata form orange color lesions on chestnut and in case of new species lesions are black in color at maturity. These morphological characters differentiate the $C$. ambiens from newly identified species, which was supported by molecular and phylogenetic data.

This study presents the first report of Cytospora castanae sp. Nov. from perennial cankers of chestnut trees, witnessed by its morphological, molecular and phylogenetic characters.

\section{Acknowledgement}

M. Dar is thankful to UGC, New Delhi (India) for providing fellowship for research. We are 
also thankful to Dr. Vaibhav Tiwari, Department of Biotechnology, SGB Amravati University, Amravati, for his valuable suggestions and help in molecular analysis. Thanks are also due to Dr. Jamaluddin, Ex-director, Forest Research Institute, Jabalpur for his help in morphological description of the fungi.

\section{References}

Adamčíková K, Juhásová G, Kobza M, Ondrušková E, 2013 - Diversity of microfungi on branches of Castanea sativa in Slovakia. Polish Botanical Journal. 58, 741-746

Adams GCA, Roux JB, Wingfield MJB. 2006 - Cytospora species ( Ascomycota , Diaporthales , Valsaceae ): introduced and native pathogens of trees in South Africa. Australasian Plant Pathology. 1818, 521-548.

Agrios GN. 2005 - Plant pathology. 5th ed. London: Academic Press. 922 pp.

Biggs AR. 1989 - Integrated control of Leucostoma canker of peach peach in Ontario. Plant Diseases 73, 869-874.

Choi YW, Hyde KD, Ho WH. 1999 - Single spore isolation of fungi. Fungal Diversity 3, 29-38.

Dar MA, Rai M. 2013 - Biological and phylogenetic analyses, evidencing the presence of Gnomoniopsis sp. in India, causing canker of chestnut trees: a new report. Indian forester 139, 37-42.

Dar MA, Rai M. 2012 - Declining population of Chestnut (Castanae sativa Mill) trees in Jammu \& Kashmir State of India by Natural and Anthropogenic Activities. Journal of Agricultural Sciences 5, 72-75

De'fago G. 1944 - Seconde contribution a`la connaissance des Valse'es v.H. Phytopathol Z 14, $103-147$.

Fan XL, Liang YM, Ma R, Tian CM. 2014 - Morphological and phylogenetic studies of Cytospora (Valsaceae, Diaporthales) isolates from Chinese scholar tree, with description of a new species. Mycoscience, 55, 252-259.

Farr DF, Bills GF, Chamuris GP, Rossman AY. 1989 - 'Fungi on plants and plant products in the United States.' (APS Press: St Paul, MN)

Fotouhifar KB, Hedjaroude GA, Leuchtmann A. 2010 - ITS rDNA phylogeny of Iranian strains of Cytospora and associated teleomorphs. Mycologia, 102(6), 1369-1382.

Grove WB. 1923 - The British species of Cytospora. Kew Bulletin. 1-30pp.

Grove WB. 1935 - British stem and leaf Fungi. Vol. 1. Sphaeropsidales. Cambridge, UK: Cambridge Univ Press. 488 pp.

Gutner LS. 1935 - Contributions to a monograph of the genus Cytospora. Trudy Botanicheskogo Instituta Aka- demii Nauk SSSR, Ser. 2. Sporovye Rasteniya 2, 411- 484.

Hubbes M. 1960 - Systematisches und physiologische Un- tersuchungen an Valse 'en auf Weiden. Phytopathol Z 39, 65-93.

Kepley JB, Jacobi WR. 2000 - Pathogenicity of Cytospora fungi on six hardwood species. Journal of Aboriculture 26, 326-332.

Kirk PM, Cannon PF, Minter DW, Stalpers JA. 2008 - Dictionary of the fungi, 10th edn. CABI publishing, Wallingford, UK. 281pp.

Larkin MA, Blackshields G, Brown NP, Chenna R, McGettigan PA, McWilliam H, Valentin F, Wallace IM, Wilm A, Lopez R, Thompson JD, Gibson TJ, Higgins DG. 2007 - Clustal W and Clustal X version 2.0. Bioinformatics 23, 2947-2948.

Lindner L. 2013 - Diagnosis of Plant Disease, Activity Report: 2013. Diagnostics www.laimburg.it/it/difesa-delle-piante/789.asp (accessed 31 Oct. 2014)

Mehrabi ME, Mohammadi GE, Fotouhifar KB. 2011. Studies on Cytospora canker disease of apple trees in Semirom region of Iran. Journal of Agricultural Technology 7, 967-982.

Rajak RC, Rai MK, Pandey AK. 1988 - Three New Ceolomycetes from Madhya Pradesh. J. of Eco. \& Tax. Bot. 12(2), 405-408. 
Sharma ND, Agarwal GP. 1974 - Fungi causing Plant Diseases at Jabalpur (M. P.) XV. Some Sphaeropsidales. Sydowia. 28, 258-265.

Singh UB. 1943 - Some diseases of fruits and fruit trees in Kumaon-I. ICAR Misc. Bull. 51-56.

Soni KK, Dadwal VS. Jamaluddin. 1983 - Three new Sphaerodosidales from India. Current Science. 52(12), 601-602.

Spaulding P. 1961- Foreign Diseases of Forest Trees of the World. U.S.D.A. Agric. Handb. 197: $1-361$.

Spielman LJ. 1985 - A monograph of Valsa on hardwoods in North America. Canadian Journal of Botany 63, 1355-1387.

Sydow HP, Buttler EJ. 1916 - Fungi Indiae Orientalis, Pars V. Ann. Mycol. 14, 177-220

Tamura K, Nei M. 1993 - Estimation of the number of nucleotide substitutions in the control region of mitochondrial DNA in humans and chimpanzees. Molecular Biology and Evolution. 10,512-526.

Tamura K, Stecher G, Peterson D, Filipski A, Kumar S. 2013 - MEGA6: Molecular Evolutionary Genetics Analysis version 6.0. Molecular Biology and Evolution. 30, 2725-2729.

Tilak SD, Rokde BG. 1964 - Fungi of Acacia arrabica L. Mycopath. Et. Mycol. Appl. 21, 200-202.

Urban Z. 1957 - Vorla "ufige Mitteilung der Ergebnisse einern Revision der Gattungen Valsa and Valsella. Preslia 29, 394-395.

Von Hoehnel F. 1917 - System der Diaportheen. Ber. Dtsch. Bot. Ges. 35: 631-638

Wang X, Huang JWL, Kang Z. 2011 - Re-evaluation of pathogens causing Valsa canker on apple in China. Mycologia, 103(2), 317-324. 